\title{
The impact of development control enforcement activities on housing quality in Calabar, Nigeria
}

\author{
Otop Oquah Otop (Ph.D), Ibok, Akarawak Nduonyikoyo (Ph.D) \\ Department of Geography and Environmental Science, University of Calabar, Nigeria
}

\begin{abstract}
This study assessed the impact of development control enforcement activities on housing quality in Calabar, Nigeria. The Data was collected using 400 copies of questionnaire, using purposive and simple random sampling techniques. The primary sources of data was employed were obtained from direct field measurement using a designed checklist from Cross River State building regulations, 1984 as amended in 1987 and questionnaire survey to determine building code violations, factors, location or spread and level of violations. The hypothesis was formulated and tested using analysis of chi square. The result stated that housing quality does not significantly depend on development control measures. Since the calculated value $X^{2}(6.830)$ is less than the tabulated $X^{2}(18.31)$, the null hypotheses $\left(\mathrm{H}_{0}\right)$ was accepted. The findings were that one of the major problems of unregulated development causing serious traffic congestion and flooding.
\end{abstract}

\section{INTRODUCTION}

$\mathrm{D}$ evelopment control is one of the most critical environmental issues in sustainable urban planning all over the world. The urban environment in developed and developing countries alike has been made ghettos as a result of poor and inappropriate planning policies vis-a-vis noncompliances with space standards approved design, and ineffective enforcement of building regulations. In Nigeria, development control came into being by the enactment of the Township Improvement Ordinance (TIO) of 1863 which was applied to Lagos colony alone. This Township Improvement Ordinance was aimed at improving public health and sanitation, controlling development and to ensure, the provision of public utilities and facilities. To date, development control has been applied in Nigeria through a series of Acts and laws, for example, the Lagos State Town and Country planning (building plan) regulations of 1986, Lagos State Urban and Regional Planning edict No 2 of 1998, as well as the Urban and Regional Planning Decree No 88 of 1992, by the Federal Government amended as Decree No 18 of 1999. The creation of Cross River State from the Eastern Region in 1967, more attention was paid to physical planning in Calabar which was the capital. Cross River State took the lead in positive land use planning when in early 1970, it embarked on the preparation of development plans (master plan) for Calabar and the major towns including Akamkpa, Ugep, Obubra, Ikom, Ogoja, and Obudu.

The master plan was to address all proposed major projects in the city, such as the residential, transportation, commercial, institution, industrial development, and recreational facilities among others. For instance, buildings have been located on waterways, approved open spaces (like access roads and recreation parks). Fuel and gas filling stations are located in built-up residential areas contrary to the provisions of the laws governing physical development in the country and the state. A very flexible framework for the orderly future development, efficient land use, infrastructure investment, environmental management, social and efficient economic growth, and a physical environment of acceptable quality is needed, (Ekpoh 2003). Like Lagos State, Cross River State building regulations of 1984 as amended in 1987, the Environmental Sanitation Enforcement (Urban area) Law 2003, and the Land Use and Allocation Act of 1978, were such regulations made in view of development control in Cross River State.

The aim of the study was to assess the impact of development control enforcement activities on housing quality in Calabar, Nigeria. The objectives were to evaluate development control measures and housing quality.

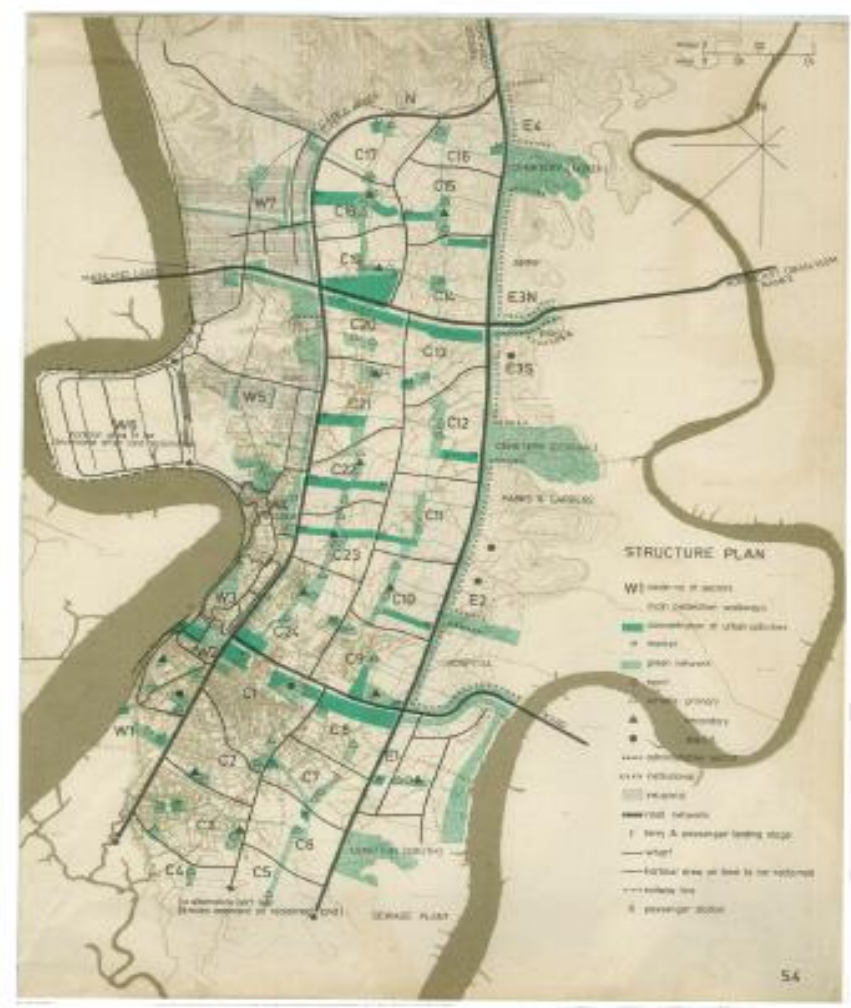

Figure 1: Calabar Master Plan (1970)

Source: Ministry of Lands and Town Planning, Cross River State 


\section{Study Area}

Calabar lies between latitudes $4.30^{\circ} \mathrm{N}$ and $5.15^{\circ} \mathrm{N}$ of equator and longitudes $8.7^{0} \mathrm{E}$ and $8.19^{\circ} \mathrm{E}$ of Greenwich meridian and has a landmass of $1480 \mathrm{sq} \mathrm{km}$. Calabar, known as Canaan city, is the capital of Cross River State, in south southNigeria. The original name for Calabar was Akwa Akpa, from the Efik language. Calabar has three (3) major kingdoms namely; Ejagham, Efut and Efik. Calabar is the capital of Cross River State. Administratively, the city is divided into Calabar Municipality and Calabar South Local Government Areas (LGAs). It has an area of four hundred and six square kilometers (406 square kilometers) and a total population of five hundred and five thousand, seven hundred and three (505,703 people) at the 2017 projected population which was calculated from 2006 census (Nigerian Population Commission, 2006).

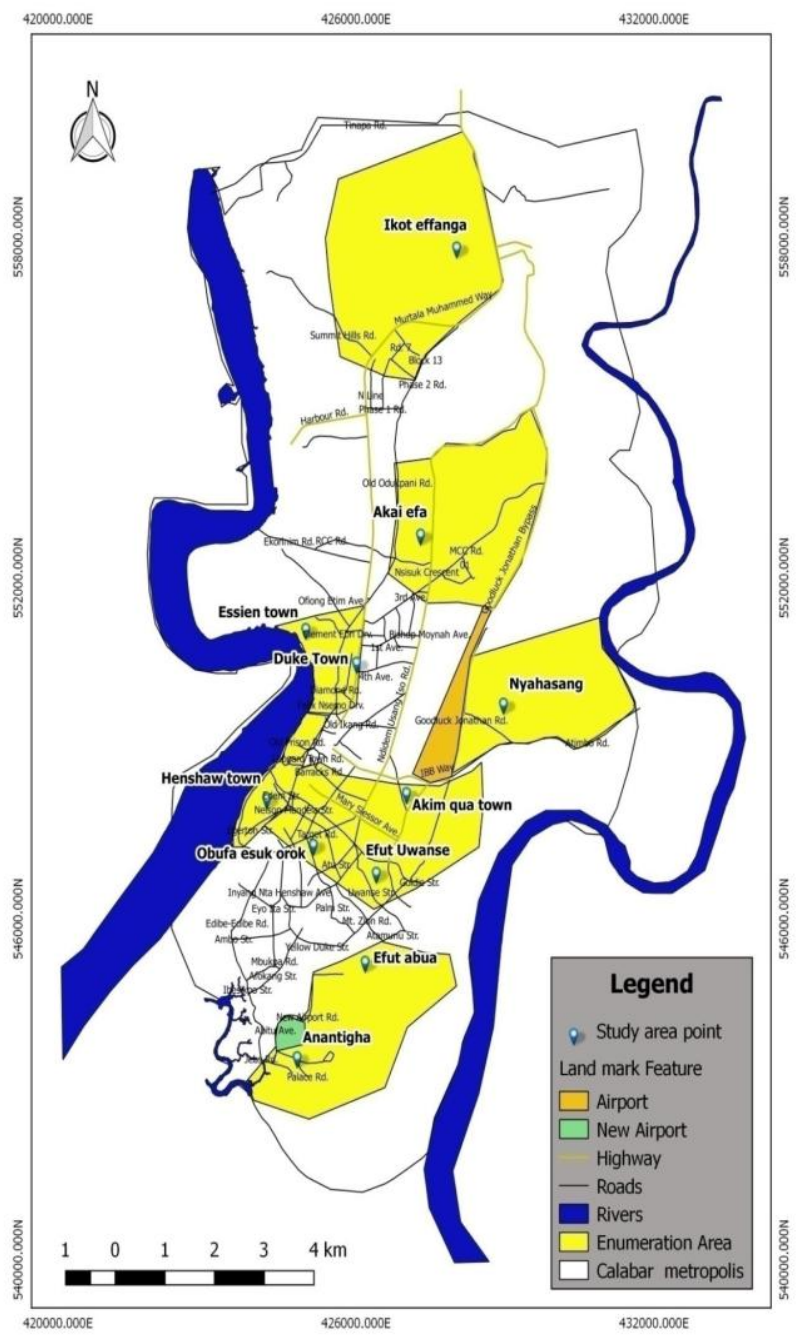

Figure 2: Map of Study Area

Source: Cross River State Survey Department

\section{Statement of the Problem}

A closely related problem is the non-conforming land uses for socio-economic activities in the study area. For example, in most areas such as Hewett, White House, Palm Street, Goldie, Calabar Road, Akim Road, Nyahasang, Ikot Ansa, etc, more than 60 percent of residential buildings are erected close to the right of way, directly under high tension cables without a proper setback. Other land uses include a commercial departmental store building in a multi-family residential zone. The use of a single family house for manufacturing furniture, for school, worship center, and fast food center without adequate parking lots, often, result in traffic congestion. The location of the Calabar ultra-modern sports stadium, less than half a kilometer from the central business district (CBD) violates the principles of Urban Land Use Planning (Richardson, 1971).

Control of physical development has huge significance for the dynamics of the built environment. Development control in large part is a critical decider of discomfort, conflict and chaos or convenience, safety and harmony in cities. Yet, land use regulations have not been adequately enforced in the metropolis. This situation has, therefore, denied residents of the metropolis the expected gains from such regulations. The planning authority or development control agencies have not been able to effectively enforce the development schemes for the metropolis. It is evident that land use control is ineffective and uncoordinated in the city of Calabar. Despite the importance of development control measures in physical environmental balancing, a series of factors still hinder its effectiveness.

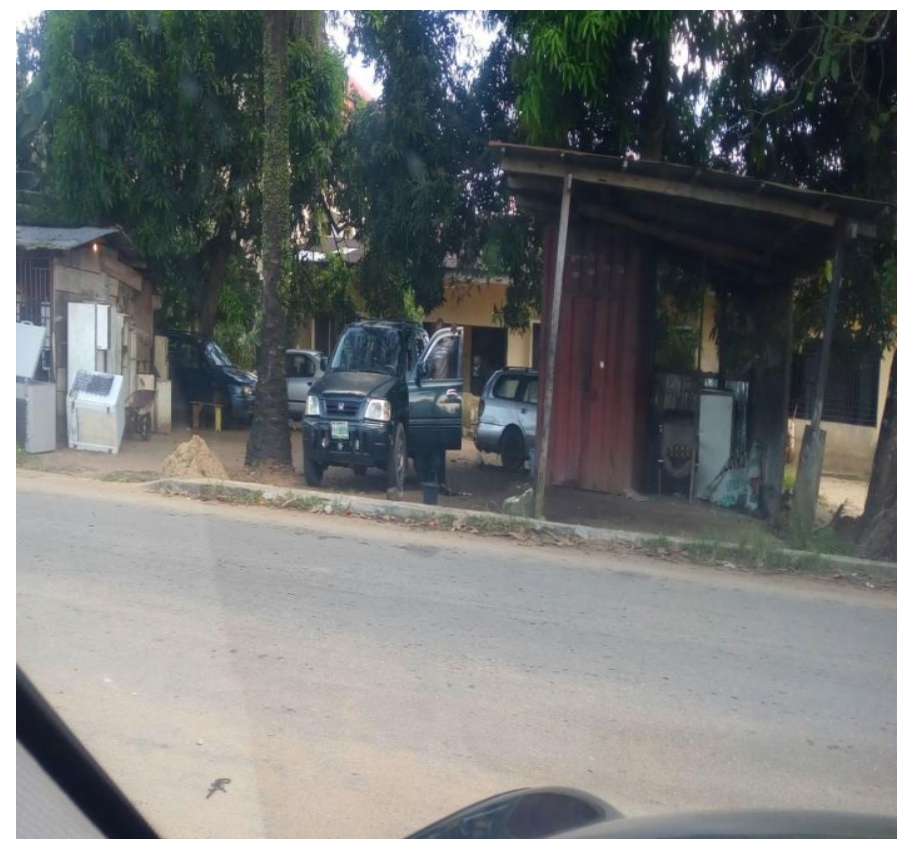

PLATE 1: Non-conforming Land Uses of Residential, Mechanic workshop and Gas Station at Essien Town in the study area.

Source: Photo taken by Author (2018) 


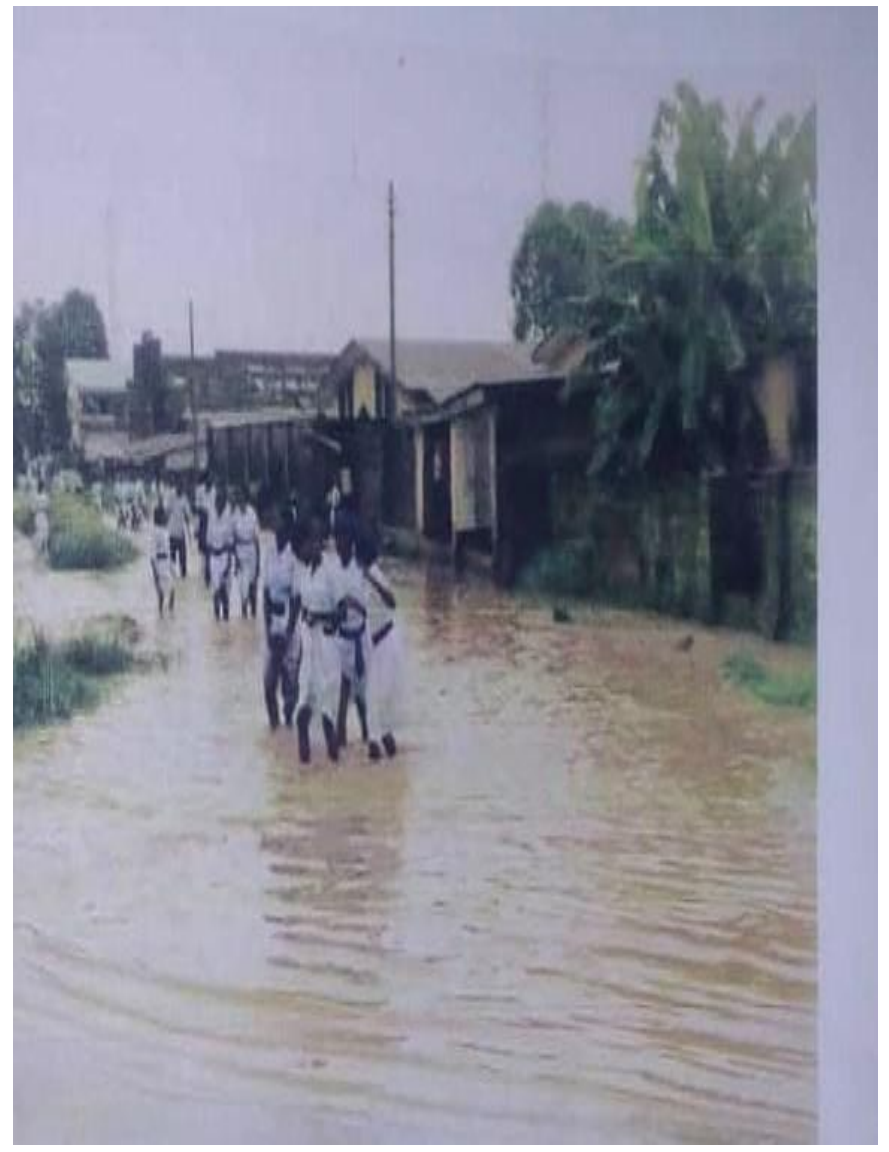

PLATE 2: Flooding due to haphazard and unregulated physical development on running water channel within Efut Uwanse

Source: Photo taken by Author (2018)

\section{LITERATURE}

Housing is of special significance since it provides many of man's cultural needs, which is his need for refuge and for rest. It also provides shelter from natural elements such as rain, harsh weather/climatic condition and from human activities. It provides security from the dangers of fire and building collapse. It provides conditions, such as good health as well as adequate space, and privacy (National Housing Policy (2000). The World Health Organization (WHO) Committee on the Public Aspects of Housing (1961) holds that: Housing is the physical structure man uses for shelter and the environs of that structure including all necessary services, facilities, equipment and devices needed or desired for the physical mental health and social well being of the family and individual'.

The Housing Acts of 1997 explained a degraded housing environment as "any area where dwellings predominate, which by reason of dilapidation, height, or sanitation facilities or any combination of these factors is detrimental to safety, health, and morals. Abumere (1987) identified poverty as a major cause of urban decay. Overcrowding in houses is a function of poverty and excessive room density results in overuse of facilities and rapid deterioration of housing structures. The study further stated that poverty is responsible for the construction of shanty structures leading to the enlargement of slums. In supporting Abumere's assertion, Habitat (2003) argued that the high rate of unemployment and situation of extreme deprivation have trapped residents of slum and informal dwellings to engage in risky sexual behavior for economic survival.

The World Bank (2005) attributed the factors of urban decay to rapid urbanization, rural-urban migration, economic downturn, the decay of urban infrastructure. Among all these, urbanization is seen as a major cause which accounts for other secondary factors and accelerates the process of urban decay. Adeagbo (1997) asserts that housing is more than shelter. It is a bundle of services. It is the totality of housing environments such as shelter, access roads, utilities such as water, electricity, sewage and the other qualities of the environment that planners refer to as housing and that where such facilities are lacking, the life of the people become unhygienic.

In the same vein, Arimah (2002) asserts that at least 220 million urban dwellers do not have access to drinking water, more than 420 million do not have access to the simplest form of sanitation and between one-third of solid wastes generated remained uncollected. The study concluded that the problems of rapid urbanization and the consequent infrastructure maintenance to create and promote the phenomenon of urban decay in our cities.

In addition, the United Nations (1991) pointed out some specific causes of environmental degradation to include, Poor application of development control and non-compliance with building codes and town planning regulations has brought about total neglect of building setbacks, air space, building codes zoning regulations, and unauthorized change of use from residential to commercial or industrial use accelerates the process of decay.

Aloa (2006) in his study of built environment decay and urban health in Nigeria, had established that inadequate basic infrastructural amenities, substandard housing, overcrowding, and poor sanitation promote health hazards and have serious adverse effects on the health of city residents. Specifically Baba and Jinadu (2001) in their study of spatial variation in the occurrence of housing environment and related diseases in Minna Metropolis, have established that low-quality residential areas of Minna are associated with a high incidence of diseases and the study concluded that 69 percent of disease occurrence in the study is explained by environmental quality.

Also, according to the Brundtland Commission Report (WCED, 1987) asserts that poverty pollutes the environment, creating environmental stress in many ways. Those who are poor and hungry often destroy their immediate environment in order to survive. They cut down forests, their livestock overgraze grassland, they overuse marginal land and in growing numbers, they crowd into congested cities with 
serious socio-economic and environmental consequences. For instance, poor families pollute the environment through indiscriminate waste disposal just as inadequate residential accommodation often results in overcrowding in decrepit and squatter settlements.

In his contribution to solving the problems, Uyanga (2003) asserts that environmental degradation undermines livelihoods, generating a vicious cycle in which poverty and declining environmental quality feed off one another. Considering the nexus, the 1972 Stockholm conference on the environment observed that: In developing countries, most of the environmental problems are caused by underdevelopment. Millions continue to live far below the minimum levels required for a decent human existence, deprived of adequate food and clothing, shelter and education, health and sanitation. Therefore, the developing countries must divert their effort development, bearing in mind their priorities and the need to safeguard and improve the environment.

According to George (1999) "a degraded environment is that in which a set of forces interact and social image of an area by a larger community which includes poor sewage, dilapidated structures, high occupancy ratio, inadequate provision of or complete lack of public facilities, ownership by absentee landlords or landladies who are not interested in maintenance of the property, physical dullness in terms of landscaping and other social amenities." More so, Encyclopaedia of urban planning defines a degraded housing environment as an area of overcrowding, squalid, closely built and un-hygienic housing". To further confirm this, a report by Prodec and Associates Nigeria Limited (1996) recorded the causes of environmental degradation in Cross River State to include: Soil erosion, flood and land degradation, 40 percent deforestation and loss of biodiversity 19 percent, solid wastes 22 percent, water pollution 15 percent and air pollution 4 percent. In addition, the report also listed 105 erosion spots in the state describing their nature and magnitude and also pointed out the factors responsible for environmental degradation to include population growth and distribution, resource ownership, and policy failure.

The degradation of the housing environment is a wide spread phenomenon in Nigeria Cities. The increasing wave of rural-urban migration coupled with the absence of job opportunities for migrants and poor urban management could be blamed for this ugly trend. However, deteriorated areas worldwide are characterized by sub-standard housing, lack of social amenities, poor refuse and waste management facilities and unsanitary conditions. The resultant effect is poor urban quality, which leads to a high incidence of diseases (Otop 2020). However, Obot (1983) and Eni (1998) assert that the obvious problems of increased urbanization include poor and inadequate housing, illegal shacks on the municipal land and the deterioration of the physical environment. Thus, as the population of cities begin to witness unprecedented explosion, the following urban problems become eminent; slums, shanty towns and squatter settlements, housing shortages manifesting in over-crowding of persons and tenements, un-sanitary and un-aesthetic urban milieu expressed in un-controlled litter of refuse or municipal wastes, homelessness forcing some residents to take shelter under bridges or broken down vehicles, mal-nutrition, despicable poverty, deficient urban social infrastructure (lack of water supply, toilets, electricity, roads, drainage), lowering of property values or blighted structures, flooding, environmentally-induced diseases, such as cholera, typhoid, etc, air, water and land pollution, loss of biodiversity, and different forms of deviant behaviour associated with sub-standard living conditions.

Standard qualities of housing standards are important and fundamental to planning. These, not only ensure the protection and comfort of residence but also promote beauty, convenience and aesthetics in the overall built-up environment. Good housing quality refers to more than a roof over one's head. It also means adequate privacy; adequate space, physical accessibility; adequate security, security of tenure, structural stability and durability; adequate lighting, heating and ventilation; adequate basic infrastructure, such as water supply, sanitation and waste-management facilities; suitable environmental quality and health-related factors; and adequate and accessible location with regard to motor able roads. All of these should be available at an affordable cost and should be determined together with the people concerned (UN - HABITAT, 2006).

\section{METHODOLOGY}

This research used the survey research method design and employed both primary and secondary sources of data. The primary data sources were questionnaire, interview, image capturing of scene at the terminals and geographical coordinates using GPS to capture the study area. The secondary data were journals books projects and maps were relevant and instituted the background information to this study. The targeted population for this study comprised of the property owners in the study area, buildings and members of staff at the department of town planning authority Calabar. The questionnaire was administered to property owners in the study area using the purposive and random sampling techniques. Also, structured interview was conducted at the department of town planning authority Calabar. The research sample size was 400 household heads randomly selected out of the 3999 completed buildings along the main access road in the eleven residential districts in the study area. This comprises of the following;

Sample Districts and Estimated Number of Buildings (Property owners)

\begin{tabular}{|c|c|c|c|}
\hline S/N & Sample districts & $\begin{array}{c}\text { Number of } \\
\text { buildings }\end{array}$ & Sample size \\
\hline 1 & Ikot Effanga & 303 & 30 \\
\hline 2 & Essien Town & 563 & 56 \\
\hline 3 & Akai Efa & 398 & 40 \\
\hline 4 & Nyahasang & 606 & 61 \\
\hline
\end{tabular}




\begin{tabular}{|c|c|c|c|}
\hline 5 & Akim Qua Town & 686 & 69 \\
\hline 6 & Anantigha & 314 & 31 \\
\hline 7 & Duke Town & 107 & 11 \\
\hline 8 & EfutAbua & 298 & 30 \\
\hline 9 & Henshaw Town & 163 & 16 \\
\hline 10 & Obufa Esuk Orok & 208 & 21 \\
\hline 11 & Efut Uwanse & 353 & 35 \\
\hline 12 & Total & $\mathbf{3 9 9 9}$ & $\mathbf{4 0 0}$ \\
\hline
\end{tabular}

Source: Otop 2020

The 400 sample size represents 10 percent of the total number of buildings in the eleven sample districts. According to Luthane and Richard (1989), it is common in research studies to use 10 percent sample size, because the sample size of 10 percent of the universe has proved to be more than adequate in past research projects.

\section{DATA AND RESULTS}

The questionnaire administered to the property owners shows that majority of the property owners in the study area have a highest qualification of senior secondary certificate examination (SSCE). Also, over 70 percent of property owners are civil servants both in service and retired, see table below.

Socio-economic factors of property owners

\begin{tabular}{|c|c|c|c|c|}
\hline S/N & $\begin{array}{c}\text { Socio- } \\
\text { economic } \\
\text { factors }\end{array}$ & & Frequency & Percentage \\
\hline & & No formal education & 13 & 3.2 \\
1. & Education & FSLC & 102 & 25.5 \\
& status & SSCE & 167 & 41.7 \\
& & Degree & 61 & 15.3 \\
& & Post graduate studies & 57 & 14.3 \\
\hline \multirow{4}{*}{2.} & & Business persons & 81 & 20.3 \\
& Occupation & Civil servants & 193 & 48.3 \\
& status & Retired civil servant & 119 & 29.7 \\
& & Unemployed & 4 & 10 \\
& & Others & 3 & 0.7 \\
\hline
\end{tabular}

The interview with members of staff admitted that the department lack skilled manpower and poorly funded. This is the principal cause of the poor monitoring of developer's activities in Calabar.

The hypothesis result on Table with $\left(\mathrm{X}^{2}=6830, \mathrm{P}=\right.$ $0.621)$ indicated that housing quality does not significantly depend on development control measures in Calabar Metropolis. Since calculated $X^{2}(6.830)$ is less than the tabulated $X^{2}(18.31)$, the null hypotheses $\left(\mathrm{H}_{0}\right)$ was accepted meaning that housing quality does not significantly depends on development control measures. The hypothesis has sufficiently addressed the impact of development control enforcement activity on housing quality in the study.

Descriptive Statistics of Housing Quality on Development Control Measures

\begin{tabular}{|l|l|l|l|}
\hline $\begin{array}{l}\text { Development Control } \\
\text { Measures }\end{array}$ & $\mathrm{N}$ & Mean & $\begin{array}{l}\text { Standard } \\
\text { Deviation }\end{array}$ \\
\hline Landuse type & 400 & 2.0300 & 1.66163 \\
\hline Nature of building & 400 & 1.9475 & 0.22331 \\
\hline Room size & 400 & 1.7050 & 0.45661 \\
\hline Foundation & 400 & 1.8325 & 0.37389 \\
\hline Corridor dimension & 400 & 1.6050 & 0.48946 \\
\hline Soundness & 400 & 2.1725 & 1.16022 \\
\hline Inspection & 400 & 1.7675 & 0.42296 \\
\hline Ceiling height & 400 & 1.7150 & 0.45198 \\
\hline Roof type & 400 & 1.1850 & 0.71558 \\
\hline Floor material & 400 & 1.8475 & 0.48459 \\
\hline Building height & 400 & 3.1325 & 1.22216 \\
\hline Overall housing quality & 400 & 1.9034 & 0.78712 \\
\hline
\end{tabular}

Chi square contingency analysis of development control measures on housing quality

\begin{tabular}{|c|c|c|c|c|}
\hline $\begin{array}{c}\text { Development Control } \\
\text { Measures } \\
\end{array}$ & $\begin{array}{c}\text { Yes } \\
\text { Responses } \\
\end{array}$ & $\begin{array}{c}\text { No } \\
\text { Responses } \\
\end{array}$ & $\begin{array}{c}\text { Chi- } \\
\text { square }\end{array}$ & P-value \\
\hline Landuse type & $20(19.075)$ & $15(15.925)$ & & \\
\hline Nature of building & $24(22.345)$ & $17(18.655)$ & & \\
\hline Room size & $16(16.352)$ & $14(13.652)$ & & \\
\hline Foundation & $18(22.345)$ & $23(18.655)$ & & \\
\hline Corridor dimension & $20(19.075)$ & $15(15.925)$ & & \\
\hline Soundness & $26(22.891)$ & $16(19.112)$ & 6.830 & 0.621 \\
\hline Inspection & $15(17.985)$ & $18(15.015)$ & & \\
\hline Ceiling height & $16(16.895)$ & $15(14.105)$ & & \\
\hline Roof type & $22(21.823)$ & $18(18.221)$ & & \\
\hline Floor material & $27(22.892)$ & $15(19.111)$ & & \\
\hline Building height & $14(16.352)$ & $16(13.652)$ & & \\
\hline $\begin{array}{c}\text { Overall housing } \\
\text { quality }\end{array}$ & 218 & 182 & & \\
\hline
\end{tabular}

Not significant at $0.05, \mathrm{df}=10$ critical $\mathrm{X}^{2}=18.31$

\section{DISCUSSION OF FINDINGS}

The study found, that one of the major problems of unregulated development causing serious traffic congestion and flooding is that of illegal occupation of land for the purpose of housing. This is technically referred to as squatting. The shelter erected by the squatters generally violates legal regulations as well as the most minimal human standards. From the findings, buildings with approved plans comply more with the regulations. This is indicative of the fact that the unsatisfactory level of quality of housing in the study area is a function of development control activities.

\section{RECOMMENDATIONS}

For effective implementation of development control, the State Government should recruit more graduate professionals into the enforcement unit of the Town Planning Department to help brace up with the envisaged challenge of 
shortage of manpower in the area. Also, since development control exercise is capital intensive, government should allocate more funds for planning schemes and programs that will take care of planning tools, equipments and mobility for effective scouting, monitoring and control.

\section{REFERENCES}

[1] Abumere, S. (1987): "Urbanisation and Urban Decay in Nigeria"; in Oniboku, AG, Olokesusi, F, and Egunyobi, Layi (eds) Urban Renewal in Nigeria. NISER CURP Urban and Regional Planning Series. Vol. IV; pp 19 - 32. Femsod Industrial Press, Ibadan, Nigeria.

[2] Adeagbo, D (1997): "Nigerian Housing”. In Adedotun O. Phillips and Tunji Titilola (eds), Nigeria in 2010, MSER, Ibadan pp. $195-$ 206.

[3] Alao, N. (2006) Housing location process and policy intricacies.The effect of slums. Nigeria Geographical Journal .20(1),26-35

[4] Arima, B. C. (2002): "The Effects of Deficient Infrastructure on Health Outcomes of Cities of Developing Countries" in Valarie Schulz (ed) Urbanisation and The Transition to Sustainability; IHOP Proceedings No. 6, Held BetweenJune 2 - 15, in Bonn, Germany pp. $26-27$.

[5] Baba, J. M. and Jinadu, A. M. (2001): analysis of spatial variation in the Occurrence of Housing Environment. Related Diseases in Minna Metropolis. A technical paper submitted to the University Board of Research; July 2001.

[6] Ekpoh, I. J. (2003). Environment: continuity and change, St. Paul's publishing and printing Coy, Calabar.
[7] Eni, D.D (1998) Slums as an index in socio-economic deprivation in Nigeria cities. A case study of Calabar municipality unpublished Ph.D Dissertation. Department of Geography and Regional Planning University of Calabar, Nigeria.

[8] George, C.k.(1999). Basic Principles and Methods of Urban and Regional Planning. Libro-Gem Publishers Lagos, Nigeria.

[9] Habitat (2003): An urbanizing world, Global Report on human Settlements, OUP, Oxford

[10] Housing Act (1997) National Housing Policy (2000).Draft on National Housing Policy for Nigeria, Lagos Federal Ministry of Works and Housing, Urban and Regional Planning Division.

[11] Nigerian Population Commission (2006). Population census.

[12] Obot, J. U. (1983). Spatial transport development planning and squatter settlement in Calabar municipality, London. African Urban Studies 13, 105-110

[13] UN-Habitat (2006) Regulatory Framework and Strategic Urban Planning and Management, A Paper presented at the African Ministerial Conference on Housing and Urban Development in Nairobi, April 3 - 4, 2006, available at http://www.unhabitat.org, assessed in October 3, 2008.

[14] United Nation Report (1991). Urban Land Policies and Land Use Control Measures, Vol.8, Pp 5 -7. New York.

[15] Uyanga, J. (2003): Environmental Deterioration and Policy Issues in Health Planning in Nigeria, in Adinna, E. N. Ekop, O. B. and Attah, V. I. (eds), Environmental Pollution and Environment in the Tropics, Enugu: SNAAP Press Ltd.

[16] World Bank, (2005). Infrastructure for development, world development report, New York,Oxford University Press

[17] World Commission on Environment and Development (1987).Our common future(New York:Oxford University Press)

[18] World Health Organization (1961). Expert Committee on the Public Health Aspect of Housing Geneva, Oxford University Press 